\title{
Blockade of C5a and C5b-9 Generation Inhibits Leukocyte and Platelet Activation during Extracorporeal Circulation
}

\author{
Christine S. Rinder, ${ }^{\star \ddagger}$ Henry M. Rinder, ${ }^{\star}$ Brian R. Smith, ${ }^{\star}$ Jane C. K. Fitch, ${ }^{\ddagger}$ Michael J. Smith, ${ }^{\$}$ Jayne B. Tracey, \\ Louis A. Matis," Stephen P. Squinto," and Scott A. Rollins" \\ Departments of * Laboratory Medicine and ${ }^{\ddagger}$ Anesthesiology, Yale University School of Medicine and Yale-New Haven Hospital, \\ New Haven, Connecticut 06510; ${ }^{8}$ Quinnipiac College, Hamden, Connecticut 06518; and "Alexion Pharmaceuticals, \\ New Haven, Connecticut 06510
}

\begin{abstract}
Complement activation contributes to the systemic inflammatory response induced by cardiopulmonary bypass. At the cellular level, cardiopulmonary bypass activates leukocytes and platelets; however the contribution of early (C3a) versus late (C5a, soluble C5b-9) complement components to this activation is unclear. We used a model of simulated extracorporeal circulation that activates complement (C3a, C5a, and C5b-9 formation), platelets (increased percentages of P-selectin-positive platelets and leukocyte-platelet conjugates), and neutrophils (upregulated CD11b expression). To specifically target complement activation in this model, we added a blocking mAb directed at the human $\mathrm{C5}$ complement component and assessed its effect on complement and cellular activation. Compared with a control mAb, the anti-human C5 mAb profoundly inhibited C5a and soluble C5b-9 generation and serum complement hemolytic activity but had no effect on C3a generation. Additionally, the anti-human C5 mAb significantly inhibited neutrophil CD11b upregulation and abolished the increase in P-selectin-positive platelets and leukocyte-platelet conjugate formation compared to experiments performed with the control mAb. This suggests that the terminal components C5a and $\mathrm{C5b}-9$, but not $\mathrm{C3a}$, directly contribute to platelet and neutrophil activation during extracorporeal circulation. Furthermore, these data identify the $\mathrm{C} 5$ component as a site for therapeutic intervention in cardiopulmonary bypass. $(J$. Clin. Invest. 1995. 96:1564-1572.) Key words: cardiopulmonary bypass $\cdot$ complement activation - receptors, leukocyte adhesion $\bullet$ platelet activation $\bullet$ antibodies, monoclonal
\end{abstract}

\section{Introduction}

Cardiopulmonary bypass (CPB $)^{1}$ is associated with an inflammatory response consisting of humoral and cellular changes that

Address correspondence to Christine S. Rinder, M.D., Department of Anesthesiology, Tompkins 3, Yale University School of Medicine, 333 Cedar Street, New Haven, CT, 06510. Phone: 203-785-2802; FAX: 203737-4111.

Received for publication 19 December 1994 and accepted in revised form 1 June 1995.

1. Abbreviations used in this paper: $\mathrm{C}$, complement component; CPB, cardiopulmonary bypass; CR, complement receptor; GVB $2+$, gelatin veronal-buffered saline; PE, phycoerythrin; sC5b-9, soluble C5b-9; TBS, Tris-buffered saline.

J. Clin. Invest.

(C) The American Society for Clinical Investigation, Inc.

0021-9738/95/09/1564/09 \$2.00

Volume 96, September 1995, 1564-1572 may contribute to both tissue injury and impaired hemostasis. Activation of complement during CPB has been implicated as one important contributor to this systemic inflammatory reaction (1-4). However, the correlation between the generation of specific activated complement components and the inflammation induced by CPB has not been defined. Primary inflammatory mediators are generated after activation of the complement cascade, including the anaphylatoxins complement component 3a (C3a) and C5a, the opsonin C3b, and the membrane attack complex C5b-9. In vitro, C5a has been shown to upregulate PMN CD11b and CD18 through mobilization of intracellular granules (5-8) and to induce lysosomal enzyme release by PMN (9). In vitro, C5b-9 is capable of inducing P-selectin expression on platelets (10), and both C5a and C5b-9 induce surface expression of P-selectin on endothelial cells $(11,12)$. The ability of C5a and C5b-9 to directly activate leukocytes, platelets, and endothelial cells indicates that inhibition of $\mathrm{C5}$ cleavage may be a useful strategy for ameliorating the inflammatory response to $\mathrm{CPB}$.

Our previous studies on leukocyte and platelet adhesion molecules have demonstrated that both PMN and monocyte CD1 $1 \mathrm{~b}$ are upregulated during clinical CPB (13). Additionally, CPB induces platelet $\alpha$-granule release $(14,15)$ and surface expression of platelet P-selectin (16) which mediates the binding of activated platelets to leukocytes (17). We have also demonstrated an increase in leukocyte-platelet conjugate formation during CPB which parallels the increase in circulating P-selectin-positive platelets $(13,18)$. Concomitant with these effects, CPB leads to decreases in other platelet adhesion receptors, specifically GPIb and GPIIb/IIIa but not GPIV (19-23).

In vitro recirculation of whole blood in an extracorporeal bypass circuit has been used extensively as a model to simulate platelet $(24,25)$ and leukocyte $(26,27)$ changes and complement activation (28) induced by CPB. In the present study, we have used this in vitro model of extracorporeal circulation to determine the role of early versus late complement components in the cellular activation induced by CPB. Our results demonstrate that blockade of C5a and C5b-9 membrane attack complex formation during extracorporeal circulation with an $\mathrm{mAb}$ directed against human $\mathrm{C} 5$ effectively inhibits platelet and PMN activation.

\section{Methods}

Monoclonal antibodies. All mAbs were used as purified whole Ig. AntiCD42b and anti-CD41 (SZ2 (29) and P2 (30); AMAC, Inc., Westbrook, ME) recognize platelet GPIb and GPIIb/IIIa, respectively. AntiCD62P (AC1.2 (31); Becton-Dickinson Immunocytometry Systems, San Jose, CA) is directed against P-selectin, an $\alpha$-granule membrane protein expressed on activated platelets. For leukocyte labeling, antiCD45 (2D1 (32); Becton-Dickinson) and anti-CD11b (33) (F6.2; Exalpha, Boston, MA) were used; these mAbs recognize the CD45 back- 
bone present on all leukocytes and the leukocyte complement receptor 3 (CR3), respectively. The anti-human C5 mAb N19/8 (34) and the isotype-matched anti-mouse C5 control mAb BB5.1 (35) are of the IgG1 subtype and were purified from mouse ascites fluid by protein $\mathrm{A}$ chromatography. The anti-human C5a mAb, clone C17/5 (34) recognizes an epitope expressed on C5a but not on intact C5. Rabbit antihuman C5a polyclonal antibody was obtained from Calbiochem Corp., La Jolla, CA.

Hemolytic assays. For in vitro experiments, both the anti-human $\mathrm{C} 5 \mathrm{mAb}$ and the anti-mouse C5 mAb were serially diluted 1:2 (100$0 \mu \mathrm{g} / \mathrm{ml}$ ) in gelatin veronal-buffered saline (GVB $2+$ buffer: $0.1 \%$ gelatin, $141 \mathrm{mM} \mathrm{NaCl}, 0.5 \mathrm{mM} \mathrm{MgCl}, 0.15 \mathrm{mM} \mathrm{CaCl}_{2}, 1.8 \mathrm{mM}$ sodium barbital [Sigma Chemical Co., St. Louis, MO]) and added in triplicate $(50 \mu \mathrm{l} /$ well) to a 96 -well microtiter plate (NUNC, Inc., Naperville, IL). Human serum was diluted to $20 \% \mathrm{vol} / \mathrm{vol}$ with GVB $2+$ buffer and added ( $50 \mu \mathrm{l} /$ well) to the rows of the same 96 -well plate such that the final concentration of human serum in each well was $10 \%$. The plate was then incubated at room temperature for $\sim 30 \mathrm{~min}$ while chicken erythrocytes (Lampire Biological Laboratories, Piperville, PA) were washed five times with $1 \mathrm{ml}$ of GVB $2+$ buffer and resuspended to a final concentration of $5 \times 10^{7} / \mathrm{ml}$ in GVB $2+$ buffer. $4 \mathrm{ml}$ of the chicken erythrocytes were sensitized by the addition of an anti-chicken red blood cell polyclonal antibody $(0.1 \% \mathrm{vol} / \mathrm{vol}$, Intercell Technologies, Hopewell, NJ), and the cells were incubated at $4^{\circ} \mathrm{C}$ for $15 \mathrm{~min}$ with frequent vortexing. The cells were then washed twice with $1 \mathrm{ml}$ of GVB $2+$ buffer and resuspended to a final vol of $2.4 \mathrm{ml}$ in GVB $2+$ buffer. $30-\mu \mathrm{l}$ aliquots of chicken erythrocytes $\left(2.5 \times 10^{6}\right.$ cells $)$ were added to the plate containing human serum and anti-C $5 \mathrm{mAb}$ as described above, mixed well, and incubated at $37^{\circ} \mathrm{C}$ for $30 \mathrm{~min}$. Each plate contained two additional wells of $30 \mu \mathrm{l}$ of identically prepared chicken erythrocytes, one incubated with GVB 2+ buffer alone (negative control) as a control for spontaneous hemolysis and the other containing $0.1 \%$ NP40 (Sigma) serving as a control for $100 \%$ lysis. The plate was then centrifuged at $1,000 \mathrm{~g}$ for $2 \mathrm{~min}$ and $85 \mu \mathrm{l}$ of the supernatant transferred to a new 96-well plate. Hemoglobin release was determined at OD 415 $\mathrm{nm}$ using a microplate reader (Bio-Rad Laboratories, Richmond, CA), and the percent hemolysis was determined using the following formula:

percent hemolysis

$=100 \times(\mathrm{OD}$ sample - OD negative control $) /$

(OD 100\% lysis - OD negative control)

Hemolytic assays to determine the complement activity in samples obtained from extracorporeal circuits were performed as described above on frozen serum samples that were rapidly thawed at $37^{\circ} \mathrm{C}$ immediately before the assay. Hemolytic assays performed to rule out the consumptive depletion of complement due to the addition of anti-human C5 $\mathrm{mAb}$ were also performed as described above except that purified rat C5 (Alexion Pharmaceuticals, Inc.) was added to human serum samples ( $50 \mu \mathrm{l} / \mathrm{well}, 10 \mu \mathrm{g} / \mathrm{ml}$ final concentration) immediately before the addition of sensitized chicken erythrocytes.

Complement activation assays (C5a,C3a, sC5b-9). The ability of the anti-human C5 mAb to block the generation of C5a in vitro as well as in the extracorporeal circulation experiments was determined using a modification of the methods of Wurzner et al. (34). A 96-well microtiter plate was coated with $50 \mu \mathrm{l} /$ well of the anti-human C5a mAb (clone $\mathrm{C} 17 / 5$ ) at a final concentration of $5 \mu \mathrm{g} / \mathrm{ml}$ in ELISA coating buffer ( $150 \mathrm{mM} \mathrm{Na}_{2} \mathrm{CO}_{3}, 348 \mathrm{mM} \mathrm{NaHCO}$, $\mathrm{pH} 9.6$ ) and incubated overnight at $4^{\circ} \mathrm{C}$. The plates were then washed three times with ELISA solution ( $200 \mu \mathrm{l} /$ well; $20 \mathrm{mM}$ Tris, $150 \mathrm{mM} \mathrm{NaCl}, 0.05 \%$ Tween-20, pH 7.5) and blocked with Tris-buffered saline (TBS)-BSA ( $200 \mu \mathrm{l} /$ well) for 1 $\mathrm{h}$ at $37^{\circ} \mathrm{C}$. The plates were washed three times, and serum samples derived from hemolytic assays as described above or from human serum samples obtained from extracorporeal circuits were added ( $50 \mu \mathrm{l} /$ well, diluted 1:21 in TBS-BSA). As a positive control for C5a release, a standard curve was generated using twofold serial dilutions of recombinant human C5a (Sigma) in TBS-BSA (0-25 ng/ml, $50 \mu \mathrm{l} /$ well). All samples were incubated at $37^{\circ} \mathrm{C}$ for $1 \mathrm{~h}$. The plate was then washed three times, and rabbit anti-human C5a polyclonal antibody (1:200 dilution in TBS-BSA) was added to each well and incubated for $1 \mathrm{~h}$ at $37^{\circ} \mathrm{C}$. The plate was then washed three times, and horseradish peroxidase-conjugated goat anti-rabbit IgG was added (1:5,000 dilution in TBS-BSA), and the plate was incubated at $37^{\circ} \mathrm{C}$ for $1 \mathrm{~h}$. After three final washes, the plate was developed with $50 \mu \mathrm{l} /$ well ELISA substrate buffer $(10 \mathrm{mg} / \mathrm{ml} O$-phenylenediamine dihydrochloride; Sigma $)$. The plate was read at OD $490 \mathrm{~nm}$ and C5a release quantified relative to the C5a standard curve.

For the measurements of fluid-phase $\mathrm{C} 3 \mathrm{a}$ and sC5b-9, blood samples were drawn at various time points from the extracorporeal circuit, spun at $4^{\circ} \mathrm{C}$, and the serum immediately frozen at $-70^{\circ} \mathrm{C}$. Samples were thawed at $37^{\circ} \mathrm{C}$ immediately before the assay, and $\mathrm{C} 3 \mathrm{a}$ and soluble $\mathrm{C} 5 \mathrm{~b}$ 9 ( $\mathrm{sC5b}-9$ ) generation were measured in triplicate using $\mathrm{C} 3 \mathrm{a}$ and $\mathrm{sC} 5 \mathrm{~b}-$ 9 ELISA kits (Quidel, San Diego, CA). C3a and sC5b-9 values were expressed as absorbance values (OD $450 \mathrm{~nm}$ ) after subtraction of background absorbance from normal human serum control samples.

Extracorporeal circuit preparation. Extracorporeal circuits were assembled using a hollow-fiber pediatric membrane oxygenator with a $1.25 \mathrm{~m}^{2}$ surface area (VP CML Plus; Cobe Cardiovascular, Arvada, $\mathrm{CO}$ ), polyvinyl chloride tubing (Tygon Class VI; Norton Performance and Plastics, Akron, $\mathrm{OH}$ ), polycarbonate connectors, and a minimally occlusive roller pump (Cardiovascular Instruments Corp., Wakefield, MA). Oxygenator and circuitry were primed with $600 \mathrm{ml}$ of lactated ringers containing dextrose $(4.0 \mathrm{~g} / \mathrm{liter})$, porcine heparin $(5,000 \mathrm{U} /$ liter final concentration; Elkins-Sinn, Cherry Hill, NJ), and mannitol (4.0 $\mathrm{g} /$ liter). The prime was warmed to $37^{\circ} \mathrm{C}$ with a cooler-heater (Sarns; $3 \mathrm{M}$ Health Care, Ann Arbor, MI) and circulated at 1.5 liters $/ \mathrm{min}$, while the sweep gas flow was maintained at 0.25 liters per min using $100 \%$ $\mathrm{O}_{2}$. The sweep gas was changed to a mixture of oxygen $(95 \%)$ and carbon dioxide (5\%) at 0.25 liters per min for $10 \mathrm{~min}$ before addition of blood to the circuit. The $\mathrm{pH}, \mathrm{PCO}_{2}, \mathrm{PO}_{2}$, and perfusate temperature were continuously monitored throughout the recirculation period using an in-line blood gas monitor (CDI TM4000; 3M Health Care, Tustin, $\mathrm{CA}$ ), and sodium bicarbonate was added as required to maintain $\mathrm{pH}$ in the range of 7.25-7.40.

Extracorporeal circuit operation and sampling. After approval by the Human Investigation Committee, blood $(500 \mathrm{ml})$ was drawn over $5 \mathrm{~min}$ from healthy volunteers on no medications into a transfer pack (Baxter Healthcare, Corp., Deerfield, IL) containing porcine heparin (5,000 U/liter final concentration) and then added to the extracorporeal circuit. For studies of complement inhibition during extracorporeal circulation, the anti-human C5 mAb N19/8, $30 \mathrm{mg}$ in sterile PBS, was added to the transfer pack immediately before addition of blood to the extracorporeal circuit. This dose of the N19/8 mAb had been shown in preliminary studies to completely block complement hemolytic activity and C5a generation in whole blood. In control runs, the anti-mouse C5 mAb BB5.1 was similarly added to the transfer pack before its addition to the circuit. As blood was introduced to the reservoir via the prime port, $200 \mathrm{ml}$ of prime fluid was simultaneously withdrawn distal to the oxygenator outlet to yield a final circuit volume of $900 \mathrm{ml}$ and a final hematocrit of $24 \% \pm 3 \%$ (mean $\pm S D$ ). Blood was circulated with prime, and complete mixing was accomplished within $2 \mathrm{~min}$; a baseline sample was drawn and designated as time 0 . The circuit was then cooled to $27^{\circ} \mathrm{C}$ over $5 \mathrm{~min}$ and maintained at that temperature for $60 \mathrm{~min}$, after which it was rewarmed to $37^{\circ} \mathrm{C}$ for an additional $30 \mathrm{~min}$ (a total of 90 min of recirculation).

Blood samples were drawn at $5,15,30,45,60,75$, and 90 min of recirculation. Serum samples were prepared by immediate centrifugation, snap frozen in liquid nitrogen, and stored at $-70^{\circ} \mathrm{C}$ until they were assayed for complement studies. For measurement of CH50, a pretreatment sample was drawn from the whole blood immediately before its addition to the extracorporeal circuit, or in the case of runs including $\mathrm{mAb}$, before addition of either the $\mathrm{N} 19 / 8 \mathrm{mAb}$ or the BB5.1 $\mathrm{mAb}$. For measurement of fluid phase $\mathrm{C} 3 \mathrm{a}$ and $\mathrm{sC} 5 \mathrm{~b}-9,200 \mu \mathrm{l}$ of serum was diluted 1:1 in sample preservative solution (Quidel) immediately before freezing. Whole-blood samples were immediately fixed in $1 \%$ ( final concentration) paraformaldehyde in PBS for flow cytometric studies. An additional whole blood sample $(1 \mathrm{ml})$ was drawn into EDTA 
( $5 \mathrm{mM}$ final concentration) at 0,30 , and $90 \mathrm{~min}$ for a complete blood count and leukocyte differential using an automated counter (STKS; Coulter Electronics, Hialeah, FL).

Fluorescence labeling. Whole-blood samples were fixed for $60 \mathrm{~min}$ at $4^{\circ} \mathrm{C}$ followed by addition of $1: 8 \mathrm{vol} / \mathrm{vol}$ of Tris-glycine as previously described (36). Samples were washed twice and resuspended in Tyrode's-Hepes buffer (Hepes $5 \mathrm{mmol} / \mathrm{liter}, \mathrm{NaCl} 140 \mathrm{mmol} / \mathrm{liter}, \mathrm{KCl}$ $2.7 \mathrm{mmol} /$ liter, dextrose $5.5 \mathrm{mmol} /$ liter, $\mathrm{NaH}_{2} \mathrm{PO}_{4} 0.42 \mathrm{mmol} /$ liter, and $\mathrm{NaHCO}_{3} 12 \mathrm{mmol} /$ liter, $\mathrm{pH}$ 7.4) and divided into aliquots for labeling. All samples were incubated with saturating concentrations of mAb at $4^{\circ} \mathrm{C}$ for $20 \mathrm{~min}$, then washed and resuspended in Tyrode's-Hepes buffer for FACS ${ }^{\circledR}$ analysis as previously detailed (37). For determination of the percentage of leukocytes with bound platelets and leukocyte activation, samples were labeled with: $(a)$ FITC-anti-CD45 and phycoerythrin (PE)-anti-GPIIb/IIIa and ( $b$ ) FITC-anti-CD45 and PE-anti-CD1 1b. For determination of platelet glycoprotein expression and activation, samples were labeled with: (c) FITC-anti-GPIb; and (d) FITC-anti-GPIIb/ IIIa and PE-anti-CD62P.

Flow cytometry. Samples were analyzed on a FACScan ${ }^{\circledR}$ flow cytometer (Becton-Dickinson). Leukocyte measurements $[(a) \&(b)]$ were carried out by live-gating on FITC-positive, leukocyte-sized events using forward- versus side-scatter parameters to differentiate between monocyte and neutrophil subsets and to exclude unbound platelets. Mean CD11b fluorescence and the percentage of leukocyte-platelet conjugates were determined as previously described $(13,38)$. Platelet analysis $[(c) \&(d)]$ was accomplished by acquisition of 10,000 FITCpositive, platelet-size events. Mean single platelet GPIb and GPIIb/IIIa fluorescence and the percentage of platelets expressing CD62P were determined as previously described $(39,40)$. An isotype-matched (PEconjugated) control mAb was used to set a threshold (99\% of events below threshold) for P-selectin expression and quantitation of leukocyteplatelet conjugates.

Statistics. All results were normalized to the time 0 value to minimize the effects of interdonor variability. Statistical analysis was performed using a multivariate ANOVA for repeated measurements over time. Statistical significance was taken at a $P$ value $<0.05$

\section{Results}

Inhibition of $C 5 b-9$ and $C 5 a$ generation by the anti-human $C 5$ $m A b$. The primary goal of this study was to use a functionally blocking $\mathrm{mAb}$ directed against the human $\mathrm{C} 5$ complement component in order to determine the contribution of the activated terminal components C5a and C5b-9 to platelet and leukocyte activation during extracorporeal circulation. To this end, in vitro assays were performed to confirm the complement-inhibitory activity of the $\mathrm{mAb}$ and to establish the dose required to block C5 activation during extracorporeal circulation. Assays performed in $20 \%$ human serum established that the anti-C5 mAb, N19/8, completely blocked C5b-9-mediated hemolytic activity at a concentration of $25 \mu \mathrm{g} / \mathrm{ml}$ (Fig. $1 A$ ). Similarly, the N19/ $8 \mathrm{mAb}$ completely blocked the generation of C5a at $25 \mu \mathrm{g} / \mathrm{ml}$, thereby confirming that this $\mathrm{mAb}$ blocks the cleavage of $\mathrm{C} 5$ to $\mathrm{C} 5 \mathrm{a}$ and $\mathrm{C} 5 \mathrm{~b}$ by the C5 convertase enzyme complex (Fig. 1 $B$ ). By contrast, an isotype-matched control mAb, BB5.1, which is directed against the mouse $\mathrm{C} 5$ complement component but does not bind human $\mathrm{C} 5$, did not block $\mathrm{C} 5 \mathrm{a}$ or $\mathrm{C} 5 \mathrm{~b}-9$ generation in these assays. Given that the concentration of $\mathrm{C} 5$ in human serum is $\sim 70 \mu \mathrm{g} / \mathrm{ml}$, these data suggest that a dose of $125 \mu \mathrm{g} /$ $\mathrm{ml}$ (a 2:1 molar ratio of $\mathrm{mAb}$ to $\mathrm{C} 5$ ) would be sufficient to completely block complement activation in whole human serum.

Complement activation during extracorporeal circulation. In order to determine the effect of the anti-human C5 mAb on complement activation during simulated extracorporeal circulation, experiments were performed in the presence of the anti-
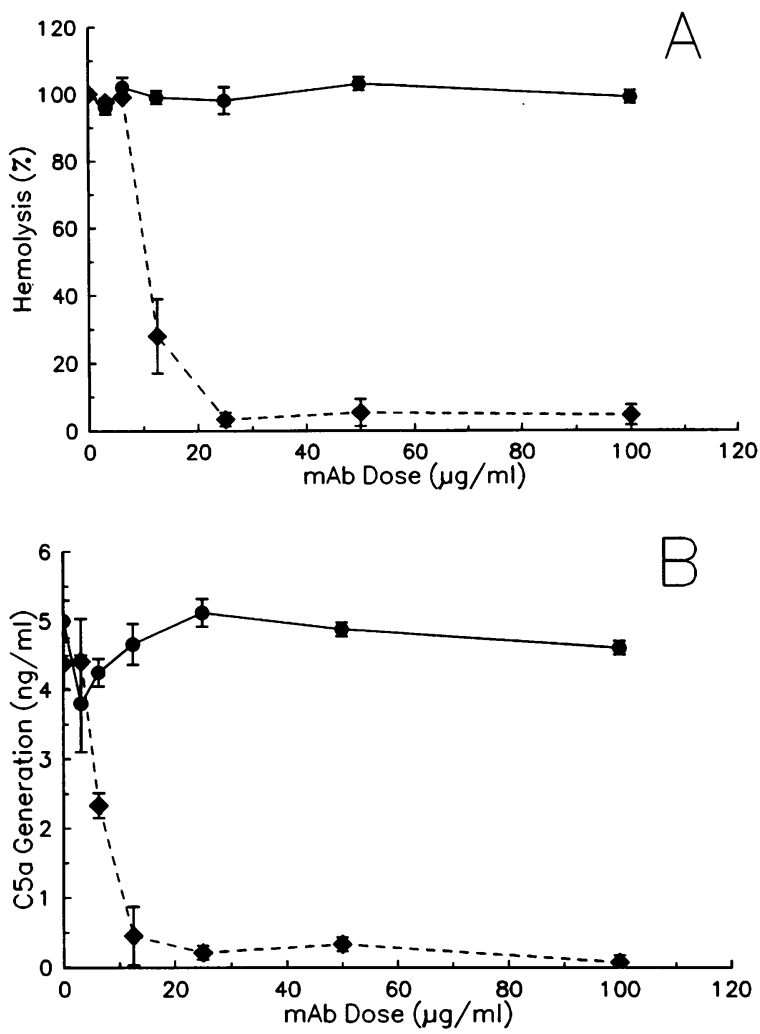

Figure 1. A mAb directed against human $\mathrm{C} 5$ blocks in vitro human complement-mediated hemolytic activity and $\mathrm{C} 5 \mathrm{a}$ generation. Human complement-mediated hemolysis $(A)$ and C5a generation $(B)$ were determined as a function of the input of an anti-human C5 mAb (clone $\mathrm{N} 19 / 8, \bullet$ ) and a control anti-mouse C5 mAb (clone BB5.1, $\bullet$ ). The assay was performed in $20 \% \mathrm{vol} / \mathrm{vol}$ human serum as described in Methods. Data are expressed as the mean \pm SD $(n=3)$ from triplicate determinations from a single experiment and are representative of three experiments.

human C5 mAb, N19/8 $(n=5)$, the isotype-matched control mAb, BB5.1 $(n=4)$, and in the absence of any added mAb, i.e., a "no-mAb" control $(n=5)$. Recirculation of blood on the extracorporeal circuit resulted in significant early complement activation in all experiments as measured by the generation of $\mathrm{C} 3 \mathrm{a}(P<.01$ for N19/8 mAb, BB5.1 control $\mathrm{mAb}$, and no$\mathrm{mAb}$ control). Furthermore, $\mathrm{C} 3 \mathrm{a}$ generation increased rapidly during the first 30 min and continued to rise throughout the 90min time course in all experiments, with no significant difference in the level of $\mathrm{C} 3 \mathrm{a}$ achieved in the presence of the antihuman $\mathrm{C} 5 \mathrm{mAb}$ as compared to the anti-mouse $\mathrm{C} 5 \mathrm{mAb}$ control $(P>.05$, Fig. $2 A)$ and compared to the no-mAb control $(P>.05)$. By contrast, the anti-human $\mathrm{C} 5 \mathrm{mAb}$ completely inhibited the generation of sC5b-9 when compared to the antimouse $\mathrm{C} 5$ control mAb $(P<.05$, Fig. $2 B)$ or the no-mAb control $(P<.001)$. These data were supported by hemolytic assays, which demonstrated that addition of the anti-human C5 mAb blocked functional complement hemolytic activity by $>95 \%$ throughout the time course of the extracorporeal circulation experiments, while hemolytic activity remained relatively unchanged in samples taken from extracorporeal circulation experiments with the anti-mouse $\mathrm{C} 5$ control $\mathrm{mAb}$ (Fig. $2 \mathrm{C}$ ) and the no-mAb control $(P<.001$, for both controls relative to the $\mathrm{N} 19 / 8 \mathrm{mAb}$ ). Addition of purified rat $\mathrm{C} 5$ to serum samples derived from experiments performed in the presence of the 

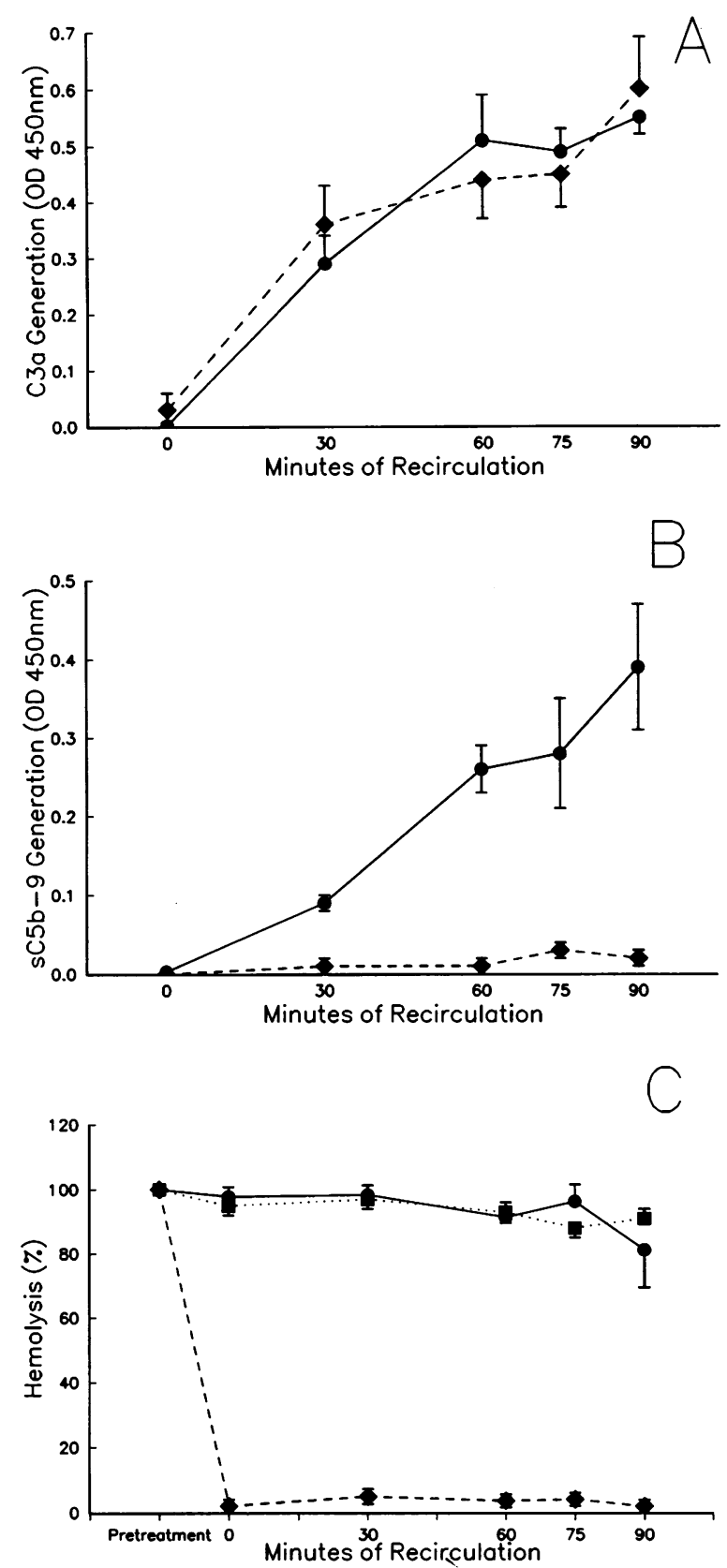

Figure 2. Activation of complement during extracorporeal circulation. Levels of C3a $(A)$, sC5b-9 $(B)$, and hemolytic activity $(C)$ were measured in serum samples taken at the time points on the abscissa. The circuit was kept at $37^{\circ} \mathrm{C}$ until time 0 , then cooled to $27^{\circ} \mathrm{C}$ over 3 min and maintained at $27^{\circ} \mathrm{C}$ until after the 60 -min sample, then rewarmed to $37^{\circ} \mathrm{C}$ for the remaining $30 \mathrm{~min}$. The mean \pm SEM from five experiments performed after addition of the N19/8 anti-C5 $\mathrm{mAb}(\bullet)$ and four experiments performed after addition of the anti-mouse C5 control $\mathrm{mAb}(\bullet)$ are shown. The anti-human C5 mAb significantly blocked generation of sC5b-9 $(B)$ and hemolytic activity $(C),(P<0.001$ for both) but not the increase in $\mathrm{C} 3 \mathrm{a}(A)$. As a control to insure that complement inhibition was specific to the $\mathrm{C} 5$ component, purified rat C5 $(10 \mu \mathrm{g} / \mathrm{ml})$ was added to human serum samples containing the $\mathrm{N} 19$ / 8 anti-human $\mathrm{C5} \mathrm{mAb}(\boldsymbol{)})$. The addition of rat C5 fully reconstituted hemolytic activity in these assays.

anti-human C5 mAb resulted in complete restoration of total hemolytic activity (Fig. $2 \mathrm{C}$ ), indicating that complement inhibition observed in the presence of the anti-human $\mathrm{C} 5 \mathrm{mAb}$

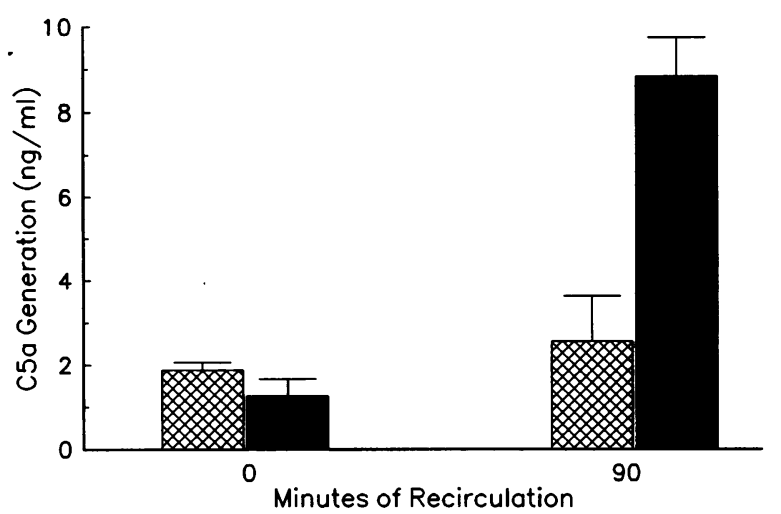

Figure 3. C5a generation during extracorporeal circulation. Levels of C5a were measured in serum samples taken at the time points indicated on the abscissa. The mean \pm SEM from five experiments performed after addition of the N19/8 anti-C5 mAb ( $\square$ ) and four experiments performed after addition of the anti-mouse $\mathrm{C} 5 \mathrm{mAb}(\square)$ are shown. The antihuman $\mathrm{C} 5 \mathrm{mAb}$ significantly blocked generation of C5a $(P<0.01)$.

was specific for C5 and not due to generalized consumption of complement components.

To further confirm that the anti-human $\mathrm{C} 5 \mathrm{mAb}$ retained the capacity to block the conversion of C5 to C5a and C5b during simulated extracorporeal circulation, as demonstrated in the static in vitro model (Fig. 1), C5a generation was measured in serum samples obtained from simulated extracorporeal circuits in the presence of the anti-human C5 MAb or control $\mathrm{mAb}$. As was demonstrated for sC5b-9 generation, addition of the anti-human C5 mAb significantly inhibited $(P<.001)$ the generation of C5a during simulated extracorporeal circulation when compared to control mAb (Fig. 3).

Leukocyte adhesion receptors. In control circuits to which the anti-mouse $\mathrm{C} 5 \mathrm{mAb}$ was added, PMN CD11b (Fig. 4) rose modestly (1.4-fold) during recirculation at $27^{\circ} \mathrm{C}$ then increased dramatically with rewarming to $37^{\circ} \mathrm{C}$, peaking at over 2.5 times baseline at $90 \mathrm{~min}$ of recirculation $(P<0.01)$. No-mAb con-

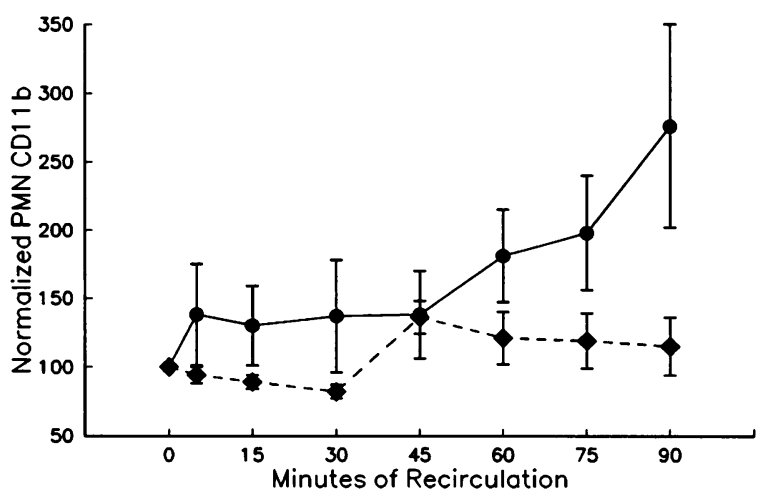

Figure 4. Neutrophil CD11b during extracorporeal circulation. Fluorescence labeling of CD11b was measured on PMN in whole blood taken at the time points shown on the abscissa and expressed as a percentage of the baseline fluorescence value. The circuit was kept at $37^{\circ} \mathrm{C}$ until time 0 , then cooled to $27^{\circ} \mathrm{C}$ over $3 \mathrm{~min}$ and maintained at $27^{\circ} \mathrm{C}$ until after the 60 -min sample, then rewarmed to $37^{\circ} \mathrm{C}$ for the remaining 30 min. The mean \pm SEM from five experiments performed after addition of the N19/8 anti-human C5 mAb ( $\bullet$ ) and four control experiments using the anti-mouse C5 control mAb $(\bullet)$ are shown. N19/8 significantly inhibited the increase in PMN CD11b $(P<0.01)$. 
trols demonstrated a similar increase in PMN CD11b ( $P$ $<0.01$ ). Addition of the anti-human C5 mAb N19/8 to the extracorporeal circuit significantly inhibited the increase in PMN CD11b when compared to the control mAb and no-mAb $(P<0.01$ for both); surface expression peaked at only 1.4 times baseline at $45 \mathrm{~min}$ of recirculation (Fig. 4). Monocyte $\mathrm{CD} 11 \mathrm{~b}$ was upregulated after addition of the anti-human C5 $\mathrm{mAb}$, but the peak CD11b expression was significantly blunted compared to the no-mAb control $(P<0.05)$. However, there was no significant difference in monocyte CD11b upregulation between the mAb control and the anti-human $\mathrm{C} 5 \mathrm{mAb}(P$ $>0.05$ ).

Platelet activation. The percentage of circulating platelets expressing P-selectin increased significantly over time during recirculation in the presence of the control $\mathrm{mAb}$, peaking at 1.5 times baseline levels after $90 \mathrm{~min}$ (Fig. $5 \mathrm{~A}$ ), and the no-mAb controls demonstrated a similar increase $(P<.05$ for both $)$. Addition of the anti-human C5 mAb completely abrogated this increase, with a peak value of only 1.03 times baseline at 30 min of recirculation $(P<0.01$ compared to both the $\mathrm{mAb}$ control [Fig. $5 \mathrm{~A}$ ] and the no-mAb control).

Platelet membrane P-selectin acts as a ligand for adhesion to monocytes and PMN; thus, leukocyte-platelet conjugate formation may represent an even more sensitive measure of platelet $\alpha$-granule release in whole blood $(38,41)$, as well as a functional measure of P-selectin activity. During extracorporeal circulation in the presence of control $\mathrm{mAb}$, the percentage of monocytes with bound platelets increased significantly ( $P$ $<0.01$ ) by twofold at $45 \mathrm{~min}$ (Fig. $5 \mathrm{~B}$ ), with an absolute average value of $74 \%$ of monocytes having bound platelets. PMN-platelet conjugate formation also significantly increased to three times baseline $(P<0.05$, Fig. $5 C)$, with an absolute average of $57 \%$ of PMN binding platelets. No-mAb controls showed similar increases in monocyte-platelet $(P<0.05)$ and PMN-platelet $(P<0.05)$ adhesion. Concomitant with the abrogation of platelet $\mathrm{P}$-selectin expression, addition of the $\mathrm{mAb}$ N19/8 completely inhibited the increase in both monocyteplatelet and PMN-platelet binding during extracorporeal circulation (Fig. 5, $B$ and $C, P<0.01$ compared to both the $\mathrm{mAb}$ control and the no-mAb control ). The peak percentage of monocyte-platelet and PMN-platelet conjugates never exceeded the baseline values of 54 and $41 \%$, respectively, in the N19/8treated experiments.

Platelet adhesion receptors. Surface expression of platelet GPIb did not change significantly during the control runs $(P$ $>0.05$ for both mAb control and no-mAb control). Addition of mAb N19/8 did not significantly alter this pattern $(P=0.91)$. Likewise, in runs using the control mAb, platelet GPIIb/IIIa did not change significantly over time $(P>0.05)$ and in the no-mAb controls decreased only marginally to $86 \%$ of control $(P<0.05)$. Addition of mAb N19/8 was associated with preservation of the surface expression of GPIIb/IIIa when compared to the no-mAb control $(P<0.05)$.

Cell counts. The absolute PMN, monocyte, and platelet counts were determined serially during extracorporeal circulation. After the initial hemodilution, normalized PMN counts significantly decreased on simulated extracorporeal circulation in the presence of the control $\mathrm{mAb}$ to $55 \%$ of baseline after 90 min of recirculation $(P<0.05$, Fig. $6 A)$. Platelet counts in the mAb control runs also significantly decreased to $55 \%$ of baseline in the first $30 \mathrm{~min}$, but rebounded at $90 \mathrm{~min}$ to $68 \%$ of baseline $(P<0.05$, Fig. $6 B)$. No-mAb controls demonstrated similar decreases in both PMN and platelet counts $(P<0.05$
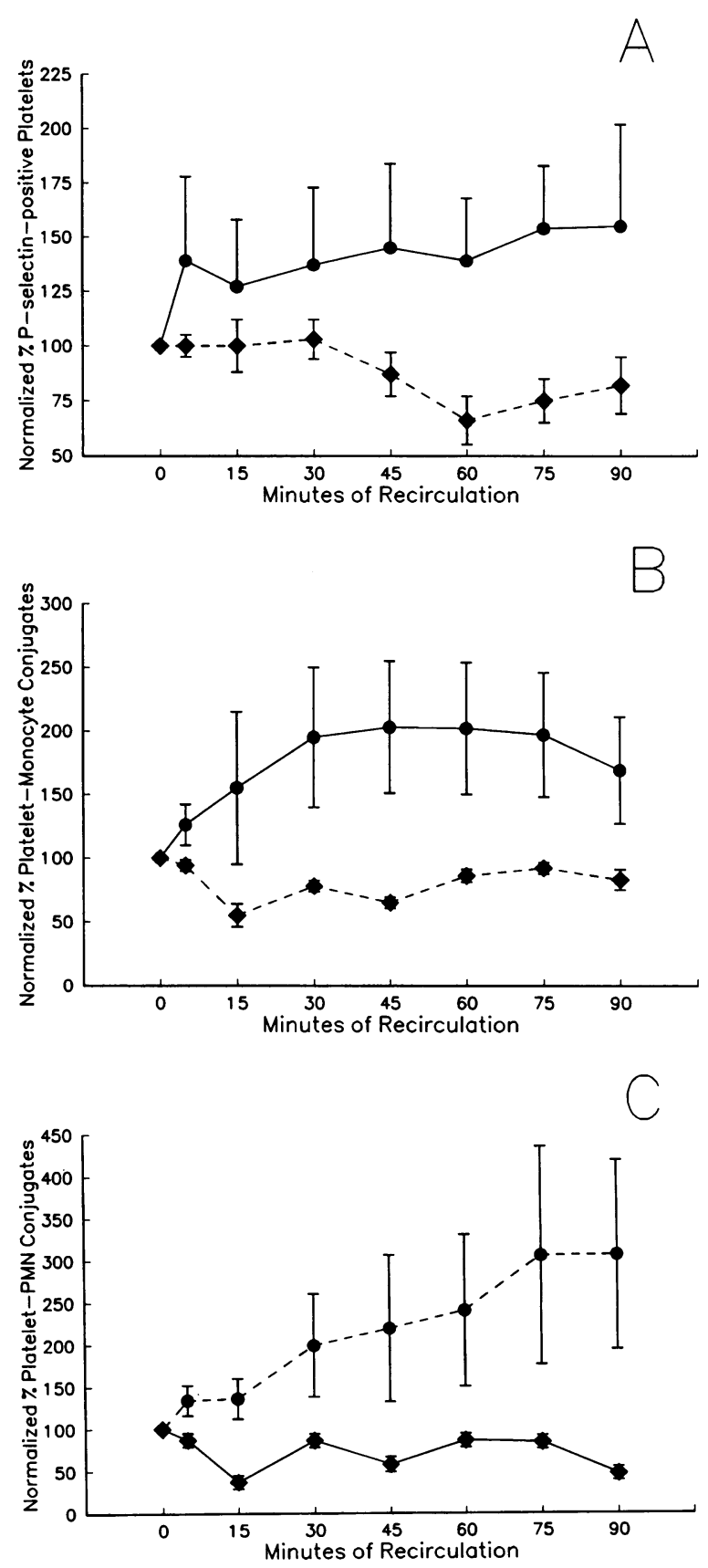

Figure 5. P-selectin-positive platelets and platelet-leukocyte adhesion during extracorporeal circulation. The percentage of circulating platelets expressing P-selectin $(A)$ and the percentage of monocytes binding platelets $(B)$ and PMN binding platelets $(C)$ were measured at the time points shown on the abscissa and normalized to the baseline value. The mean \pm SEM from five experiments performed after addition of the $\mathrm{N} 19$ / 8 anti-human $\mathrm{C} 5 \mathrm{mAb}(\bullet)$ and four control experiments using the anti-mouse C5 mAb (•) are shown. The N19/8 mAb significantly inhibited the increase in the percentage of circulating P-selectin-positive platelets and the increase in formation of monocyte-platelet and PMN-platelet conjugates $(P<0.01$ for all $)$.

for both). Addition of the anti-C5 mAb N19/8 resulted in significant $(P<0.05)$ preservation of both PMN and platelet counts, with an average decrease to only 81 and $91 \%$ of baseline, respectively. Monocyte counts also decreased during control extracorporeal circulation experiments, although the de- 

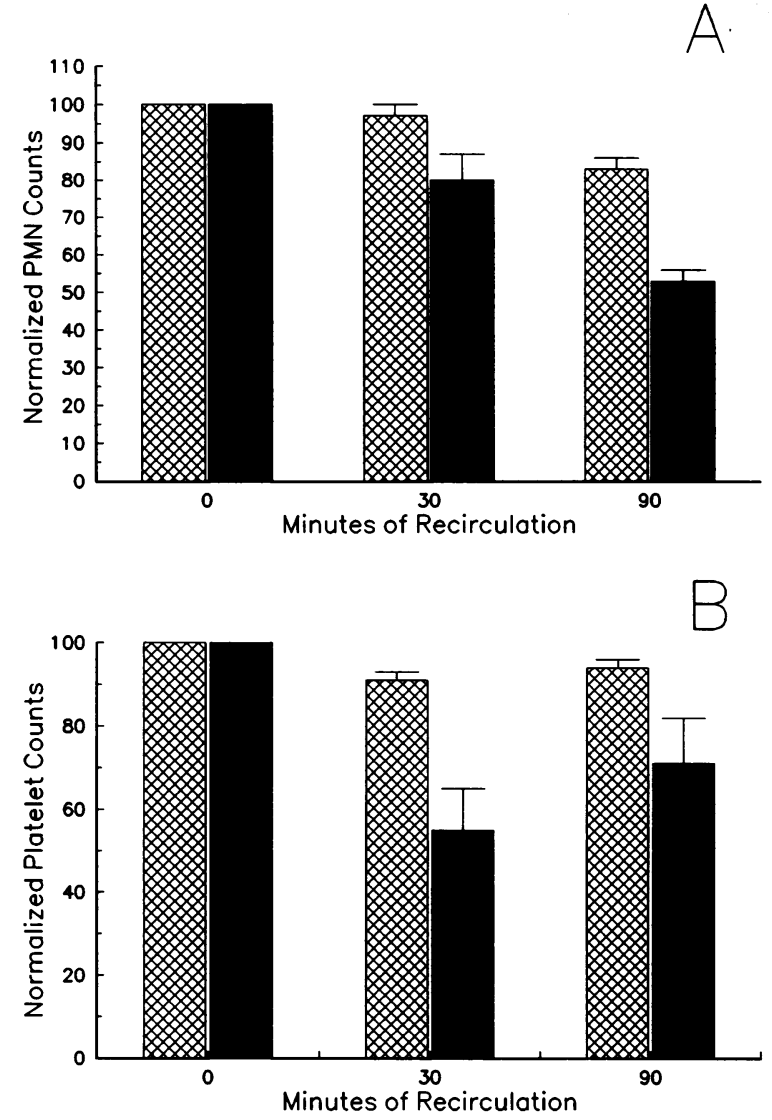

Figure 6. Normalized PMN and platelet counts during extracorporeal circulation. The absolute number of PMN $(A)$ and platelets $(B)$ was measured at the time points shown on the abscissa and normalized to the baseline value. The hatched bars ( $\square$ ) represent the mean \pm SEM for the five runs to which N19/8 was added, and the solid bars ( $\square$ ) represent the mean \pm SEM for the four runs using the anti-mouse C5 control mAb. Compared to control mAb, addition of the mAb N19/8 significantly inhibited the decrease in PMN counts at $90 \mathrm{~min}$ and the decrease in platelet counts at $30 \mathrm{~min}$ on the extracorporeal circuit $(P<0.05$ for both).

crease did not reach statistical significance in the case of the no-mAb control. Addition of the N19/8 mAb significantly preserved the monocyte count when compared to the control $\mathrm{mAb}$ $(P<0.05)$.

\section{Discussion}

In this study, we have demonstrated that blockade of the terminal complement cascade using an mAb directed at human C5 effectively inhibits the activation of platelets and neutrophils associated with an in vitro model of extracorporeal circulation. Previous studies have demonstrated that complement activation occurs during CPB (1-4). Additionally, the role of complement in the associated morbidity and mortality has been indirectly demonstrated in a number of studies (42-44), where indices of cardiac and pulmonary dysfunction in adults and multisystem organ failure in infants and children correlated significantly with complement activation. However, the exact role of the various activated complement products such as $\mathrm{C} 3 \mathrm{a}, \mathrm{C} 3 \mathrm{~b}, \mathrm{C} 5 \mathrm{a}$, and C5b-9 in the induction of many of the specific cellular changes associated with CPB is ill-defined because of the paucity of effective complement inhibitors. Cleavage of C3 as a marker of complement activation has been shown to correlate with patient morbidity in some studies (42-45) but not in others (4, 46). The failure of $C 3$ activation products to correlate with levels of sC5b-9 during in vivo CPB (47) indicates that in this setting C3a may not be an adequate surrogate marker for morbidity related to the terminal complement components. These data underscore the importance of determining whether activated terminal complement components C5a and C5b-9 are important in the pathophysiology of CPB.

Blockade of complement activation could be undertaken at any one of the steps of the final common pathway. Although both C3a and C5a are classified as anaphylatoxins, C5a has additional pro-inflammatory properties (48). Its ability to activate both neutrophils and endothelial cells $(5-9,12)$ suggests a greater role for $\mathrm{C} 5 \mathrm{a}$ in the inflammatory response to $\mathrm{CPB}$, making it an important focus for designing complement inhibitor therapeutics. The ability of the membrane attack complex, (C5b-9), to cause vesiculation of platelets (10) and endothelial cells $(11,49)$ and formation of prothrombotic microparticles $(10,50)$ also suggests a role for this mediator in some of the thrombotic complications after CPB. C3b is a by-product of C3 cleavage and promotes opsonization of bacteria by leukocytes. Congenital deficiencies in $\mathrm{C} 3$ are associated with recurring, life-threatening bacterial infections (51). By contrast, complete deficiency of the more terminal complement components C5C9 leads to an increased susceptibility principally to uncommon infections with Neisseria species, but a strikingly lower mortality rate when infections do develop compared with Neisseria infections resulting from other underlying causes (48). Thus, the development of complement inhibitors that block the generation of both $\mathrm{C} 5 \mathrm{a}$ and $\mathrm{C} 5 \mathrm{~b}-9$ might significantly attenuate the inflammatory response to $\mathrm{CPB}$, while preserving the more vital immunoregulatory functions associated with continued production of $\mathrm{C} 3 \mathrm{~b}$.

As demonstrated in the in vitro experiments measuring C5b9-mediated hemolysis, the anti-human $\mathrm{C} 5 \mathrm{mAb}$ potently inhibits the cleavage of $\mathrm{C} 5$ by $\mathrm{C} 5$ convertase, where the antimouse $\mathrm{C} 5 \mathrm{mAb}$ has no detectable reactivity for human $\mathrm{C5}$. Similarly, the anti-human $\mathrm{mAb}$ but not the anti-mouse $\mathrm{C5}$ $\mathrm{mAb}$ was able to prevent generation of $\mathrm{C} 5 \mathrm{a}$, a fragment that possesses potent anaphylatoxin activity and stimulates neutrophil chemotaxis (52). In the present study, the effect of the anti-human C5 mAb on complement activation was studied in a model of simulated extracorporeal circulation (53) in which human blood was recirculated through a membrane oxygenator. Complement activation by the extracorporeal circuit is thought to occur via both the classical and the alternative complement pathways (28). In these experiments, levels of C3a rose progressively with recirculation in the presence of either the antimouse C5 mAb or the anti-human C5 mAb, or in the absence of any $\mathrm{mAb}$. Moreover, the peak levels of $\mathrm{C} 3 \mathrm{a}$ were comparable in all three groups, confirming the previous findings (34) that the anti-human $\mathrm{C} 5 \mathrm{mAb}$ does not inhibit formation of $\mathrm{C} 3 \mathrm{a}$. These data also suggest that the anti-human C5 mAb does not form an immune complex that results in consumptive depletion of complement, as this would produce significantly higher levels of $\mathrm{C} 3 \mathrm{a}$ generation. By contrast, complement hemolytic activity, sC5b-9 complex formation, and C5a generation were all significantly inhibited by addition of the anti-human C5 mAb when compared to control experiments. Addition of purified rat C5 to serum samples taken from runs employing the antihuman C5 mAb completely reconstituted serum hemolytic ac- 
tivity, further supporting the selective inhibition of human C5 cleavage by this $\mathrm{mAb}$, as opposed to consumptive depletion of complement components.

We have previously reported that in vivo CPB results in significant upregulation of CD11b on both PMN and monocytes in the circulation (13). CD11b/CD18 is a member of the integrin family of receptors and mediates PMN adhesion to and diapedesis through endothelial cells $(33,54,55)$. PMN CD11b/ CD18-mediated adhesion is also necessary for $\mathrm{H}_{2} \mathrm{O}_{2}$ secretion in response to the PMN agonists $\mathrm{N}$-formyl-methionyl-leucylphenylalanine and platelet activating factor $(56,57)$. In animal models, antibodies to CD11b have been shown to attenuate the myocardial and pulmonary injury associated with infarction and reperfusion $(58,59)$ and the injury associated with activation of complement by cobra venom factor (60). In humans, CD11b has been shown to be upregulated on PMN and monocytes across the coronary circulation in patients with unstable angina (61). Thus, CD11b/CD18 upregulation may result from, as well as contribute to, tissue damage induced by ischemia. Although the precise mechanism of CD11b/CD18 upregulation in vivo remains uncertain, activated complement components (5-8) and contact activation with kallikrein formation (28) have been implicated as agonists for CD11b upregulation. Functionally, CD11b/CD18 on leukocytes also plays a procoagulant role, acting as a receptor for (62) and coordinator of the activation of coagulation Factor X (63).

In this study, both PMN and monocyte CD11b levels increased significantly with recirculation of blood on the extracorporeal circuit, to a level comparable to that which has been previously noted in vivo $(13,18)$. Again, the mechanism(s) responsible for upregulation of $\mathrm{CD} 11 \mathrm{~b}$ in this and other models of CPB are unclear. Moat et al. (27) have previously reported increases in sC5b-9 generation and PMN CD11b in a temporally parallel fashion on an extracorporeal circuit, but they were unable to demonstrate a direct link between the two events, nor were they able to distinguish the contributions of early complement components, such as $\mathrm{C} 3 \mathrm{a}$, versus later components. In one model comparing C3-deficient dogs and control dogs undergoing CPB (64), C3-deficient dogs had significantly less upregulation of PMN CD18 when compared to control dogs. In a piglet model of CPB in which soluble complement receptor type 1 was used to block complement activation (65), complementinhibited piglets showed better postoperative pulmonary vascular resistance but a comparable impairment in post-CPB oxygenation and lung histology as control piglets. Leukocyte $\mathrm{CD} 11 \mathrm{~b} / \mathrm{CD} 18$ was not measured in the latter study, and terminal complement products were not measured in either of these models, making the role of specific complement products in the upregulation of leukocyte CD11b difficult to ascertain.

The present study suggests that C5a and/or C5b-9 formation during extracorporeal circulation plays a major role in human PMN CD11b upregulation. The greater quantitative loss of PMN total counts in control runs of the extracorporeal circuit compared with anti-human $\mathrm{C} 5 \mathrm{mAb}$-treated runs suggests that upregulation of PMN CD11b may also be associated with functional changes in PMN adhesion as well. In vitro C5a has previously been shown to mobilize $\mathrm{CD} 11 \mathrm{~b}$ from intracellular compartments in PMN (6-8), making C5a a likely contributor to $\mathrm{CD11b}$ upregulation during extracorporeal circulation. By contrast, the contribution of the early complement anaphylatoxin C3a to PMN activation appears to be less important in this model of CPB in the absence of terminal complement activation. However, monocyte CD11b upregulation during simulated ex- tracorporeal circulation was not affected by inhibition of terminal complement components when compared to the control $\mathrm{mAb}$, and only blunted compared to the no-mAb control, suggesting that although $\mathrm{C} 5 \mathrm{a}$ is also capable of stimulating granule release in this cell type (66), its role in monocyte CD11b upregulation during extracorporeal circulation may be less significant than its role in PMN CD11b upregulation.

Recirculation during control-simulated extracorporeal circulation also resulted in an increase in the percentage of circulating-activated platelets and a decrease in total platelet numbers, as reported in vivo $(13,18)$ and in other extracorporeal circulation models (67). In parallel with platelet activation, simulated extracorporeal circulation resulted in the formation of plateletmonocyte and platelet-PMN conjugates, which has also been reported in vivo $(13,18)$. Although the consequences of leukocyte-platelet adhesion in the setting of CPB are not well defined, evidence points toward a prothrombotic role for these conjugates (68-70). Addition of the anti-human C5 mAb to the extracorporeal circuit abolished the increases in circulating Pselectin-positive platelets, monocyte-platelet and PMN-platelet conjugates, and attenuated platelet sequestration. This blunting of platelet activation and activation-dependent conjugate formation by the anti-C5 mAb may be due to its inhibition of C5b9 formation, which has been shown to induce $\alpha$-granule release and P-selectin expression (10), although inhibition of C5a, which induces P-selectin expression in endothelial cells (12), may also play a role.

Decreases in the vWf receptor, GPIb, and the fibrinogen receptor GPIIb/IIIa during in vivo CPB have been postulated to be due to several mechanisms including $(a)$ the actions of plasmin $(71),(b)$ binding of the GPIIb/IIIa complex to fibrinogen adsorbed to the perfusion circuit during extracorporeal circulation, $(c)$ fragmentation/vesiculation of the platelet, and (d) internalization of either GPIb or GPIIb/IIIa $(72,73)$. The absence of major changes in both platelet receptors GPIb and GPIIb/IIIa in the extracorporeal model in the presence of the control $\mathrm{mAb}$ and clinically inconsequential decreases in the absence of $\mathrm{mAb}$ support the hypothesis that decreases noted in vivo $(19,21,22)$ reflect the actions of plasmin (70) which is not generated in this in vitro model of extracorporeal circulation (28).

In summary, the changes in neutrophil and platelet activation receptors and in leukocyte-platelet conjugate formation induced by recirculation of whole blood during simulated extracorporeal circulation are similar to those observed during in vivo $\mathrm{CPB}$. Addition of a blocking $\mathrm{mAb}$ to the human $\mathrm{C} 5 \mathrm{com}-$ plement component during simulated extracorporeal circulation significantly abrogated the upregulation of PMN CD11b, the increase in platelet $\mathrm{P}$-selectin, and the formation of P-selectindependent PMN-platelet and monocyte-platelet conjugates. We conclude that C5a and C5b-9 generation may play a major role in cellular activation during $\mathrm{CPB}$ and suggest that a $\mathrm{C} 5$ inhibitor may represent a potent therapeutic intervention for blocking the CPB-induced inflammatory response.

\section{Acknowledgments}

The authors thank the perfusionists of Yale-New Haven Hospital for their expertise and assistance in setting up the model of extracorporeal circulation.

Supported by National Institutes of Health (NIH) grants HL-47193 (B. R. Smith) and HL-02668 (H. M. Rinder) and Alexion Pharmaceuticals. Christine Rinder is a recipient of an American Heart Association 
Clinician-Scientist Award, and Henry Rinder is a recipient of an NIH Physician-Scientist Award.

\section{References}

1. Parker, D., J. Cantrell, R. Karp, R. Stroud, and S. Digerness. 1972. Changes in serum complement and immunoglobulins following cardiopulmonary bypass. Surg. Annu. 71:824-827.

2. Haslam, P., P. Townsend, and M. Branthwaite. 1980. Complement activation during cardiopulmonary bypass. Anaesthesia. 25:22-26.

3. Salama, A., F. Hugo, D. Heinrich, R. Hoge, R. Muller, V. Kiefel, C. Hueller-Eckhardt, and S. Bhakdi. 1980. Deposition of terminal C5b-9 complement complexes on erythrocytes and leukocytes during cardiopulmonary bypass. $N$. Engl. J. Med. 318:408-414.

4. Steinberg, J., D. Kapelanski, J. Olson, and J. Weiler. 1993. Cytokine and complement levels in patients undergoing cardiopulmonary bypass. J. Thorac. Cardiovasc. Surg. 106:1008-1016.

5. Springer, T. A., W. S. Thompson, L. J. Miller, F. C. Schmalstieg, and D. C Anderson. 1984. Inherited deficiency of the Mac-1, LFA-1, p150,95 glycoprotein family and its molecular basis. J. Exp. Med. 160:1901-1918.

6. Anderson, D. C., F. C. Schmalsteig, M. J. Finegold, B. J. Hughes, R. Rothlein, L. J. Miller, S. Kohl, M. F. Tosi, R. L. Jacobs, and T. C. Waldrop. 1985. The severe and moderate phenotypes of heritable Mac-1, LFA-1 deficiency: their quantitative definition and relation to leukocyte dysfunction and clinical features. J. Infect. Dis. 152:668-689.

7. Tonnesen, M. G., D. C. Anderson, T. A. Springer, A. Knedler, N. Avdi, and P. M. Henson. 1989. Adherence of neutrophils to cultured human microvascular endothelial cells: stimulation by chemotactic peptides and lipid mediators and dependence upon the Mac-1, LFA-1, p150,95 glycoprotein family. J. Clin. Invest. 83:637-646.

8. Fletcher, M. P., G. Stahl, and J. Longhurst. 1993. C5a-induced myocardial ischemia: role for CD18-dependent pmn localization and PMN-platelet interactions. Am. J. Physiol. 265 (Heart Circ. Physiol. 34):H1750-H1761.

9. Chenowith, D., and T. Hugli. 1978. Demonstration of specific C5a receptor on intact human polymorphonuclear leukocytes. Proc. Natl. Acad. Sci. USA 75:3943-3947.

10. Wiedmer, T., and P. Sims. 1991. Participation of protein kinases in complement C5b-9-induced shedding of platelet plasma membrane vesicles. Blood. 78:2880-2886

11. Hattori, R., K. K. Hamilton, R. D. Fugate, R. P. McEver, and P. J. Sims 1989. Complement proteins C5b-9 induce secretion of high molecular weight multimers of endothelial von Willebrand factor and translocation of granule membrane protein GMP-140 to the cell surface. J. Biol. Chem. 264:9053-9060.

12. Foreman, K. E., A. A. Vaporciyan, B. K. Bonish, M. L. Jones, K. J. Johnson, M. M. Glovsky, S. M. Eddy, and P. A. Ward. 1994. C5a-induced expression of P-selectin in endothelial cells. J. Clin. Invest. 94:1147-1155.

13. Rinder, C., J. Bonan, H. Rinder, J. Mathew, R. Hines, and B. R. Smith. 1992. Cardiopulmonary bypass induces leukocyte-platelet adhesion. Blood. 79:1201-1205.

14. Geng, J. G., M. P. Bevilacqua, K. L. Moore, T. M. McIntyre, S. M. Prescott, J. M. Kim, G. A. Bliss, G. A. Zimmerman, and R. P. McEver. 1990 Rapid neutrophil adhesion to activated endothelium mediated by GMP-140. $\mathrm{Na}$ ture (Lond.). 343:757-761.

15. Berman, C. L., E. L. Yeo, J. D. Wencel-Drake, B. C. Furie, M. H. Ginsberg, and B. Furie. 1986. A platelet alpha granule membrane protein that is associated with the plasma membrane after activation. J. Clin. Invest. 78:130-137.

16. Rinder, C., J. Bonnert, H. Rinder, J. Mitchell, K. Ault, and R. Hillman. 1991. Platelet activation and aggregation during cardiopulmonary bypass. Anes thesiology. 74:388-393.

17. Hamburger, S. A., and R. P. McEver. 1990. GMP-140 mediates adhesion of stimulated platelet to neutrophils. Blood. 75:550-555.

18. Rinder, C. S., D. Gaal, L. Student, and B. R. Smith. 1994. Plateletleukocyte activation and modulation of adhesion receptors in pediatric patients with congenital heart disease undergoing cardiopulmonary bypass. J. Thorac. Cardiovasc. Surg. 107:280-288.

19. George, J. N., E. B. Pickett, S. Saucerman, R. P. McEver, T. J. Kunicki, N. Kieffer, and P. J. Newman. 1986. Platelet surface glycoproteins: studies on resting and activated platelets and platelet membrane microparticles in norma subjects, and observations in patients during adult respiratory distress syndrome and cardiac surgery. J. Clin. Invest. 78:340-348.

20. Wenger, R. K., H. Ludasiewicz, B. S. Mikuta, S. Niewiarowski, and L. H. Edmunds, Jr. 1989. Loss of platelet fibrinogen receptors during clinical cardiopulmonary bypass. J. Thorac. Cardiovasc. Surg. 97:235-239.

21. Rinder, C. S., J. Mathew, H. Rinder, J. Bonan, K. Ault, and B. R. Smith. 1991. Modulation of platelet surface adhesion receptors during cardiopulmonary bypass. Anesthesiology. 75:563-570.

22. Van Oeveren, W., M. P. Hander, K. L. Roozendaal, L. Eijsman, and H. J. Wildeveer. 1990. Aprotinin protects platelets against the initial effect of cardiopulmonary bypass. J. Thorac. Cardiovasc. Surg. 99:788-797.

23. Kondo, C., K. Tanaka, K. Takagi, T. Shimono, H. Shinpo, I. Yada, H.
Yuasa, M. Kusagawa, N. Akamatsu, and K. Tanque. 1993. Platelet dysfunction during cardiopulmonary bypass surgery with special reference to platelet membrane glycoproteins. ASAIO (Am. Soc. Artif. Intern. Organs) Trans. 39:M550M553.

24. Hennesy V. L., Jr., R. K. Hicks, S. Niewiarowski, L. H. Edmunds, Jr., and R. W. Colman. 1977. Effects of surface area and composition on the function of human platelets during extracorporeal circulation. Am. J. Physiol. 2132:H622H628.

25. Wachtfogel, Y., J. Musial, B. Jenkine, S. Niewiarowski, L. H. Edmunds, Jr., and R. W. Colman. 1985. Loss of platelet $\alpha_{2}$-adrenergic receptors during simulated extracorporeal circulation: prevention with prostaglandin $\mathrm{E}^{\prime}$. J. Lab. Clin. Med. 105:601-607.

26. Kappelmayer, J., A. Bernabie, L. H. Edmunds, Jr., T. Edgington, and R. W. Colman. 1993. Tissue factor is expressed on monocytes during simulated extracorporeal circulation. Circ. Res. 72:1075-1081.

27. Moat, N., N. Rebuck, D. Shore, T. Evans, and A. Finn. 1993. Humoral and cellular activation in a simulated extracorporeal circuit. Ann. Thorac. Surg. 56:1509-1514.

28. Wachtfogel, Y., P. Harpel, L. H. Edmunds, Jr., and R. W. Colman. 1989. Formation of $\mathrm{Cl}_{\mathrm{s}}-\mathrm{C} 1$-inhibitor, kallikrein-C1-inhibitor, and plasmin- $\boldsymbol{\alpha}_{2}$-plasmininhibitor complexes during cardiopulmonary bypass. Blood. 73:468-471.

29. Ruan, C., X. Du, X. Xi, P. A. Castaldi, and M. C. Berndt. 1987. A murine glycoprotein Ib complex monoclonal antibody SZ2 inhibits platelet aggregation induced by ristocetin and collagen. Blood. 69:570-574.

30. McGregor, J. L., J. Brochier, F. Wild, G. Follea, M. C. Trzeciak, E. James, M. Dechavanne, L. McGregor, and K. Clemetson. 1983. Monoclonal antibodies against platelet membrane glycoproteins. Eur. J. Biochem. 131:427-436.

31. Larsen, E., A. Celi, G. E. Gilbert, B. C. Furie, J. K. Erban, R. Bonfanti, D. D. Wagner, and B. Furie. 1989. PADGEM protein: a receptor that mediates the interaction of activated platelets with neutrophils and monocytes. Cell. 59:305-312.

32. Beverley, P. C. L. 1980. Production and use of monoclonal antibodies in transplantation immunology. In Transplantation and Clinical Immunology XI. J. Touraine, J. Trager, H. Betuel, J. Brochier, J. Dubernard, J. Revillard, and R. Triau, editors. Elsevier Science Publishers, Amsterdam, The Netherlands. 87-103.

33. Arnaout, M. A. 1990. Structure and function of the leukocyte adhesion molecules CD11/CD18. Blood. 75:1037-1050.

34. Würzner, R., M. Schulze, L. Happe, A. Franzke, F. Bieber, M. Oppermann, and O. Götze. 1991. Inhibition of terminal complement complex formation and cell lysis by monoclonal antibodies. Complement Inflammation. 8:328-340.

35. Frei, Y., J. D. Samris, and B. Stockinger. 1987. Generation of a monoclonal antibody to mouse C5: Application to an ELISA for detection of anti-C5 antibodies. Mol. Cell. Probes. 1:141-149.

36. Rinder, H. M., J. Bonan, C. S. Rinder, K. A. Ault, and B. R. Smith. 1991. Activated and unactivated platelet adhesion to monocytes and neutrophils. Blood. 78:1760-1769.

37. Ault, K. A., H. M. Rinder, J. G. Mitchell, C. S. Rinder, C. T. Lambrew, and R. S. Hillman. 1989. Correlated measurement of platelet release and aggregation in whole blood. Cytometry. 10:448-455.

38. Rinder, H. M., J. Bonan, C. S. Rinder, K. A. Ault, and B. R. Smith. 1991. Dynamics of leukocyte-platelet adhesion in whole blood. Blood. 78:173-176.

39. Shattil, S. J., M. Cunningham, and J. A. Hoxie. 1987. Detection of activated platelets in whole blood using activation-dependent monoclonal antibodies and flow cytometry. Blood. 70:307-315.

40. Rinder, H. M., M. Murphy, J. G. Mitchell, J. Stocks, K. A. Ault, and R. S. Hillman. 1991. Progressive platelet activation with storage: evidence for shortened survival of activated platelets after transfusion. Transfusion (Bethesda). 31:409414.

41. Yeo, E., and C. Gemmell. 1993. Minimal P-selectin content required for platelet-leukocyte adhesion. Blood. 82(Suppl. 1):621a.

42. Chenoweth, K., S. Cooper, T. Hugli, R. Stewart, E. Blackstone, and J. Kirklin. 1981. Complement activation during cardiopulmonary bypass: evidence for generation of C3a and C5a anaphylatoxins. N. Engl. J. Med. 304:497-503.

43. Kirklin, J. K., S. Westaby, E. Blackstone, J. W. Kirklin, K. Chenoweth, and A. Pacifico. 1983. Complement and the damaging effects of cardiopulmonary bypass. J. Thorac. Cardiovasc. Surg. 86:845-857.

44. Seghaye, M., J. Duchateau, G. Grabitz, M. Faymonville, J. Messmer, K. Buro-Tathsmann, and G. von Bernuth. 1993. Complement activation during cardiopulmonary bypass in infants and children: relation to postoperative multiple system organ failure. J. Thorac. Cardiovasc. Surg. 106:978-987.

45. Moore, F., K. Warner, S. Assousa, C. R. Valeri, and S. Khuri. 1988. The effects of complement activation during cardiopulmonary bypass. Ann. Surg. 208:95-103.

46. Seghaye, M. C., J. Duchateau, R. Grabitz, G. Nitsch, C. Marcus, B. Messmer, and G. von Bernuth. 1994. Complement, leukocytes, and leukocyte elastase in full-term neonates undergoing cardiac operation. J. Thorac. Cardiovasc. Surg. 108:29-36.

47. Videm, V., E. Fosse, T. Moones, P. Garred, and J. Svennivig. 1992. Time for new concepts about measurement of complement activation by cardiopulmonary bypass? Ann. Thorac. Surg. 54:725-731. 
48. Williams, L., W. Burks, and R. Steele. 1988. Complement: function and clinical relevance. Ann. Allergy. 60:293-300.

49. Hamilton, K. K., R. Hattori, C. T. Esmon, and P. J. Sims. 1990. Complement proteins C5b-9 induce vesiculation of the endothelial plasma membrane and expose catalytic surface for assembly of the prothrombinase complex. J. Biol. Chem. 265:3809-3814.

50. Sims, P., T. Wiedmer, C. Esmon, H. Weiss, and S. Shattil. 1989. Assembly of the platelet prothrombinase complex is linked to vesiculation of the platelet plasma membrane. Studies in Scott syndrome: an isolated defect in platelet procoagulant activity. J. Biol. Chem. 264:17049-17054.

51. Ross, S., and P. Densen. 1984. Complement deficiency states and infection: epidemiology, pathogenesis and consequences of neisserial and other infections in an immune deficiency. Medicine (Baltimore). 63:243-73.

52. Tonnesen, M. G., L. A. Smedly, and P. M. Henson. 1984. Neutrophilendothelial interactions. Modulation of neutrophil adhesiveness induced by complement fragments C5a and C5a des arg and formyl-methionyl-leucyl-phenylalanine in vitro. J. Clin. Invest. 74:1581-1592.

53. Addonizio, V. P., E. Macarak, K. Nicolaou, L. H. Edmunds, Jr., and R. W. Colman. 1979. Effects of prostacyclin and albumin on platelet loss during in vitro simulation of extracorporeal circulation. Blood. 53:1033-1042.

54. Albelda, S., and C. Buck. 1990. Integrins and other cell adhesion molecules. FASEB J. 4:2868-2880.

55. Smith, C. W., S. D. Marlin, R. Rothlein, C. Toman, and D. C. Anderson. 1989. Cooperative interactions of LFA-1 and Mac-1 with intercellular adhesion molecule- 1 in facilitating adherence and transendothelial migration of human neutrophils in vitro. J. Clin. Invest. 83:2008-2017.

56. Shappell, S., C. Toman, D. Anderson, A. Taylor, M. Entman, and C. Smith. 1990. Mac-1 (CD11b/CD18) mediates adherence-dependent hydrogen peroxide production by human and canine neutrophils. J. Immunol. 144:27022711

57. Nathan, C., S. Srimal, C. Farber, E. Sanchez, L. Kabash, A. Asch, and B. R. Succhesi. 1989. Cytokine-induced respiratory burst of human neutrophils dependence on extracellular matrix proteins and CD11/CD18 integrins. J. Cell. Biol. 109:1341-1349.

58. Simpson, P. J., R. F. Todd III, J. C. Fantone, J. K. Mickelson, J. D. Griffin, and B. R. Lucchesi. 1988. Reduction of experimental canine myocardial reperfusion injury by a monoclonal antibody (anti-Mol, anti-CD11b) that inhibits leukocyte adhesion. J. Clin. Invest. 81:624-629.

59. Todd R., III, P. Simpson, and B. Lucchesi. 1988. Anti-inflammatory properties of monoclonal anti-Mol (CD11b/CD18) antibodies in vitro and in vivo. In Leukocyte Adhesion Molecules. T. A. Springer, D. C. Anderson, A Rosenthal, and R. Rothlein, editors. Springer-Verlag, New York, Inc., New York. $125-137$.

60. Mulligan, M., C. Smith, D. Anderson, R. Todd III, M. Miyasaka, T. Tamatani, T. Issekutz, and P. A. Ward. 1993. Role of leukocyte adhesion molecules in complement-induced lung injury. J. Immunol. 150:2401-2406.

61. Mazzone, A., S. De Servi, G. Ricevuti, I. Mazzucchelli, G. Fossate, D.
Pasotti, E. Bramucci, L. Angoli, F. Marsico, G. Specchia, and A. Notario. 1993 Increased expression of neutrophil and monocyte adhesion molecules in unstable coronary artery disease. Circulation. 88:358-363.

62. Altieri, D., and T. Edgington. 1988. The saturable high affinity association of factor X to ADP-stimulated monocytes defines a novel function of the Mac-1 receptor. J. Biol. Chem. 263:7007-7015.

63. Altieri, D., J. Morrissey, and T. Edgington. 1988. Adhesive receptor Mac1 coordinates the activation of factor $\mathrm{X}$ on stimulated cells of monocytic differentiation: an alternative initiation of the coagulation protease cascade. Proc. Natl. Acad. Sci. USA. 85:7462-7466.

64. Gillinov, A. M. J. M. Redmond, J. Winkelstein, K. Zehr, A. Herskowitz, W. Baumgartner, and D. Cameron. 1994. Complement and neutrophil activation during cardiopulmonary bypass: a study in the complement-deficient dog. Ann. Thorac. Surg. 57:345-352.

65. Gillinov, A. M., P. DeValeria, J. Winkelstein, I. Wilson, W. Curtis, D. Shaw, C. G. Yeh, A. Rudolph, W. Baumgartner, A. Herskowitz, and D. Cameron 1993. Complement inhibition with soluble complement receptor type 1 in cardiopulmonary bypass. Ann. Thorac. Surg. 55:619-624.

66. Miller, L. J., D. F. Bainton, N. Borregaard, and T. A. Springer. 1987. Simulated mobilization of monocyte Mac-1 and p150,95 adhesion proteins from an intracellular vesicular compartment to the cell surface. J. Clin. Invest. 80:535544.

67. Addonizio, V. P., J. B. Smith, J. Strauss III, R. W. Colman, and L. H. Edmunds, Jr. 1980. Thromboxane synthesis and platelet secretion during cardiopulmonary bypass with bubble oxygenator. J. Thorac. Cardiovasc. Surg. 79:9196.

68. Marcus, A. J. 1990. Thrombosis and inflammation as multicellular processes: pathophysiologic significance of transcellular metabolism. Blood. 76:1903-1907.

69. Valles, J., M. T. Santos, A. J. Marcus, L. B. Safier, M. J. Broekman, N. Islam, H. L. Ullman, and J. Aznar. 1993. Downregulation of human platelet reactivity by neutrophils. Participation of lipoxygenase derivatives and adhesive proteins. J. Clin. Invest. 92:1357-1365.

70. Celi, A., G. Pellegrini, R. Lorenzet, A. De Blasi, N. Ready, B. C. Furie, and B. Furie. 1994. P-selectin induces the expression of tissue factor on monocytes. Proc. Natl. Acad. Sci. USA. 91:8767-8771.

71. Adelman, B., A. D. Michelson, J. Loscalzo, J. Greenberg, and R. I. Handin. 1985. Plasmin effect on platelet glycoprotein Ib-von Willebrand factor interactions. Blood. 65:32-37.

72. Musial, J., S. Niewiarowski, D. Hershock, T. Morinelli, R. W. Colman, and L. H. Edmunds, Jr. 1985. Loss of fibrinogen receptors from the platelet surface during simulated extracorporeal circulation. J. Lab. Clin. Med. 105:514522.

73. Gluszko, P., B. Rucinski, J. Musial, T. Wenger, A. Schmaier, R. W. Colman, L. H. Edmunds, Jr., and S. Niewiarowski. 1987. Fibrinogen receptors in platelet adhesion to surfaces of extracorporeal circuit. Am. J. Physiol. 252:H615H621. 